\title{
PETA WISATA DIGITAL MENUJU DESA CIMENYAN DESA WISATA AMAN PASCA PANDEMI
}

\author{
Tika Novis Putri ${ }^{1}$, Yolanda Azhar ${ }^{2}$, Madani Geusanrumaksa ${ }^{3}$ \\ ${ }^{1}$ Jurusan Arsitektur, Universitas Langlangbuana Bandung \\ Email: tikanovis.unla@gmail.com \\ 2 Jurusan Arsitektur, Universitas Langlangbuana Bandung \\ Email: yolandazhar@gmail.com \\ ${ }^{3}$ Jurusan Teknik Informatika, Universitas Langlangbuana Bandung \\ Email: madanigeusan15@gmail.com
}

\begin{abstract}
The COVID-19 pandemic has had a global impact on all aspects of human life including tourism. The COVID-19 crisis pandemic has caused a major fall in tourism activity around the world, especially in Bandung, West Java. According to data from the Ministry of Tourism and Creative Economy (Kemenparenkraf) there were around 1 million workers unemployed in tourism sector. This condition is also felt by the tourism sector and MSMEs in Cimenyan Village, Bandung, West Java. Regulations regarding activity restrictions, prohibitions for tourist attractions to operate, as well as dine-in restrictions for restaurant, coffee shops, and cafes have resulted a decreasing of the Cimenyan Village's people's income and caused a massive unemployment in this sector. With the closure of several tourist attractions in Cimenyan Village, namely Puncak Bintang, Kampoeng Bamboe, as well as cafes and coffee shops along the Cimenyan Village's main road, hundreds of villagers have lost their livelihoods. The weakening of trade and people's purchasing power also affected the MSMEs sector, especially in main MSME's commodities, like peuyeum, chips, and coffee. Nowadays, post-pandemic economic recovery efforts have begun to be encouraged, especially in the tourism sector. Facing "The Real New Normal", Cimenyan Village develop strategies to prepare themselves. Through the Student Real Work Lecture Program (KKNM) and the Community Service Program, offer a recovery strategy through a Digital Mapping of the Potential for Pandemic Safe Tourism (Pandemic-safe tourism) and MSMEs in Cimenyan Village. The output of this activity is a Digital Map of Pandemicsafe Tourism which can be a socialization of healthy, safe, and comfortable tourism alternatives, as well as the leading MSMEs information media in Cimenyan Village that can support existing tourism activities.
\end{abstract}

Keywords: Pandemic-safe tourism, Digital Mapping, Digital Map, Tourism Village,

ABSTRAK
Pandemi Covid-19 telah berdampak secara global terhadap seluruh aspek kehidupan manusia. Salah satu sector yang cukup terpukul akibat pandemic covid-19 ini adalah sector pariwisata. Menurut data Kementrian Pariwisata dan Ekonomi Kreatif (Kemenparenkraf) mencatat sekitar 1 juta pekerja di sector pariwisata menganggur akibat pandemi covid 19 tahun lalu. Kondisi ini juga turut dirasakan oleh sector pariwisata dan UKM di Desa Cimenyan. Aturan mengenai pembatasan kegiatan, larangan bagi tempat wisata untuk beroperasi, serta larangan dine-in bagi tempat makan, warung kopi, kafe, dan sejenisnya mengakibatkan menurunnya pendapatan masyarakat Desa Cimenyan serta meningkatkan angka pengangguran. Dengan ditutupnya beberapa tempat wisata di Desa Cimenyan, yaitu Puncak Bintang, Kampoeng Bamboe, serta kafe-kafe dan warung kopi sepanjang jalan di wilayah utara Desa Cimenyan, mengakibatkan ratusan warga desa kehilangan mata pencaharian. Melemahnya perdagangan dan daya beli masyarakat juga turut mempengaruhi sector UMKM, khususnya komoditi utama desa yaitu peuyeum, keripik, dan kopi. Tahun ini, upaya pemulihan ekonomi paska-pandemi pada sector pariwisata mulai digalakkan. Menghadapi “The Real New Normal", Desa Cimenyan sebagai turut menyusun strategi untuk mempersiapkan diri. Melalui Program Kuliah Kerja Nyata Mahasiswa (KKNM) serta Program Pengabdian Masyarakat, strategi pemulihan pariwisata dan perdagangan post pandemic adalah dengan melakukan Pemetaan Potensi Wisata Aman Pandemi (Pandemic-safe tourism), serta UMKM unggulan di Desa Cimenyan. Output kegiatan ini adalah Peta Digital Wisata Ramah Pandemi yang dapat menjadi sosialisasi alternatif wisata yang sehat, aman, serta nyaman, sekaligus media informasi UMKM unggulan Desa Cimenyan yang dapat mndukung kegiatan pariwisata yang sudah ada.

Kata Kunci: Wisata Aman Pandemi, Peta Digital, Desa Wisata 


\section{PENDAHULUAN}

Desa Cimenyan merupakan sebuah desa di wilayah utara Kecamatan Cimenyan, Kabupaten Bandung yang menjadi lokasi kegiatan Pengabdian kepada Masyarakat (PKM) 2021, Universitas Langlangbuana, Bandung. Desa Cimenyan berada pada dataran tinggi yang memiliki potensi lingkungan dan kondisi masyarakat yang beragam. Salah satu potensi Desa Cimenyan berada pada sektor ekonomi pariwisata yang merupakan salah satu sektor yang berkembang pesat di Desa Cimenyan . Berlokasi di wilayah dataran tinggi dengan view Kota Bandung, pariwisata di Desa Cimenyan sebagian besar berkembang sebagai destinasi wisata outdoor dengan kafe-kafe dan warung-warung kopi yang tersebar sepanjang jalan utama desa dengan pemanfaatan view Kota Bandung baik di siang maupun malam hari.
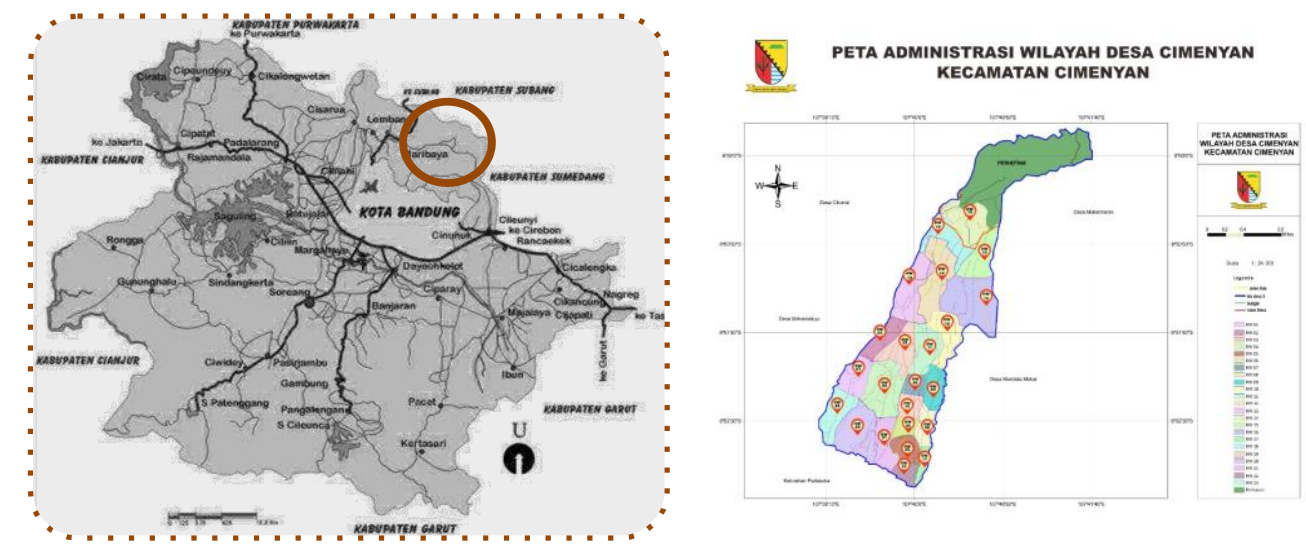

Gambar 1. Peta lokasi desa Cimenyan

Pandemi Covid 19 yang terjadi sejak awal tahun 2020 turut memberi dampak pada sektor pariwisata dan komersial di Desa Cimenyan. Pembatasan kegiatan menyebabkan tempat wisata ditutup serta kafe dan warung kopi dibatasi pelayanannya dengan hanya memperbolehkan pemesanan makanan untuk dibawa pulang (takeaway). Hal ini berdampak pada menurunnya pendapatan masyarakat yang menggantungkan mata pencahariannya pada sektor pariwisata desa. Tidak hanya berimbas pada tempat wisata dan kafe, dampak pandemic turut dirasakan oleh penggiat UMKM dalam hal ini yaitu produsen peuyeum, kopi, serta keripik. Kurangnya sosialisasi, menyebabkan tidak banyak orang yang mengetahui bahwa peuyeum adalah komoditas unggulan Desa Cimenyan yang memasok sebagian toko oleh-oleh besar di Kota Bandung.

Berdasarkan hasil observasi, pendataan, dan survei lapangan yang telah dilakukan oleh abdimas Bersama dengan mahasiswa Universitas Langlangbuana di Desa Cimenyan, terdapat beberapa permasalahan-permasalahan yang diidentifikasi, antara lain:

1. Kondisi ekonomi sebagian masyarakat Desa Cimenyan yang menurun sejak pandemic covid 19, khususnya yang bekerja pada sector pariwisata, perdagangan, dan UMKM.

2. Belum adanya pemetaan potensi wilayah Desa Cimenyan, khususnya yang berkaitan dengan tempat wisata, UMKM, dan sebagainya.

3. Pemerintah Desa Cimenyan memiliki misi mewujudkan Desa Digital, akan tetapi website resmi Desa Cimenyan terakhir diperbaharui pada tahun 2019 serta Desa Cimenyan belum memiliki peta digital yang dapat diakses dari website.

4. Belum terintegrasinya sistem pengelolaan informasi mengenai potensi lokal di Desa Cimenyan. 
5. Belum tersosialisasikannya potensi tempat wisata, kafe dan warung kopi semioutdoor yang dapat dijadikan referensi tempat rekreasi yang relatif aman pasca pandemi covid 19 di Desa Cimenyan.

6. Belum terosialisasikannya potensi UMKM local yang memiliki peluang untuk mendukung sector pariwisata Desa Cimenyan sebagai oleh-oleh maupun penganan khas local yang bias dinikmati oleh pengunjung, seperti peuyeum, keripik, kopi serta hasil perkebunan.

Berdasarkan permasalahan tersebut, serta melihat potensi Desa Cimenyan yang memiliki visi untuk menjadi desa digital, diperlukan sebuah inovasi serta sosialisasi terkait kesiapan Desa Cimenyan untuk membuka diri seiring menurunnya kasus covid 19 di Jawa Barat dan persiapan seluruh tempat wisata untuk dibuka dengan konsep "The Real New Normal". Pemetaan digital (Digital Mapping) terkait tempat-tempat wisata serta kafe-kafe dan warung kopi yang aman di masa pasca pandemi (Pandemic-safe Tourism) ini menjadi solusi alternative yang kami angkat dalam kegiatan PKM ini. Pada akhirnya, semoga kegiatan PKM ini dapat menjadi bagian dari perwujudan visi Desa Cimenyan sebagai Desa Digital yang dapat mengembangkan potensi daerahnya untuk memberikan sebesar-besarnya manfaat khususnya untuk warganya dan masyarakat pada umumnya.

\section{Strategi pariwisata pasca pandemi Covid 19}

Berbagai strategi untuk pemulihan pariwisata mulai dilakukan di berbagai tempat. Dalam berbagai forum, Sandiaga Uno memaparkan 3 langkah pemulihan pariwisata di Indonesia, yaitu inovasi produk dan tujuan wisata sesuai trend, Adaptasi dan kolaborasi, serta focus pada segmen tujuan wisata domestic. Adaptasi terhadap kondisi pandemic covid 19 adalah dengan menerapkan protocol kesehatan (mencuci tangan, mengenakan masker, menggunakan hand sanitizer, menjaga jarak), serta kolaborasi dengan melibatkan berbagai pihak serta kepentingan untuk bersama-sama memulihkan kembali sektor pariwisata tanpa mengabaikan aspek kesehatan dan keselamatan atau dengan kata lain mengembangkan Pariwisata yang Aman Pandemi (Pandemic-safe tourism).

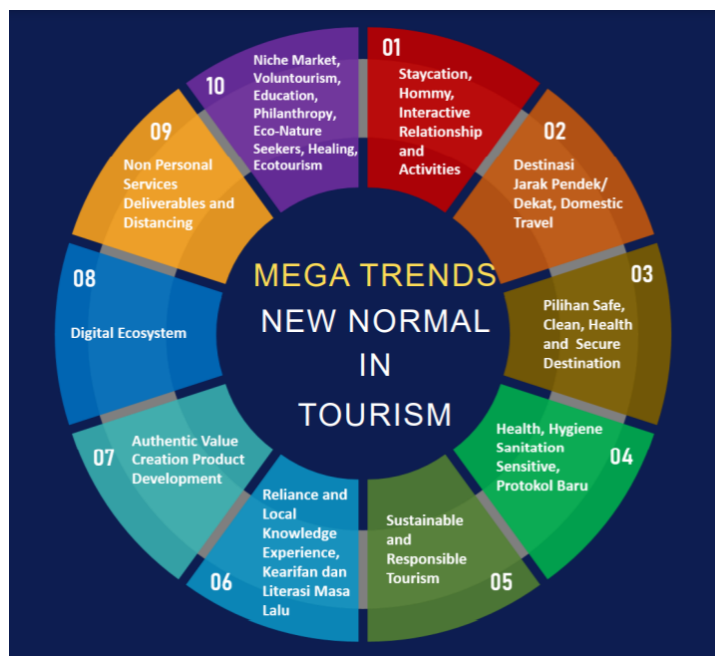

Gambar 2. Mega trends new normal in tourism

Sumber: https://www.uph.edu/wp-content/uploads/2020/06/290520_MPAR_Webinar_UPH_TheFuture-of-Tourism-and-Hospitality-Business-Model-in-the-New-Normal_Frans-Teguh.pdf) 
Berdasarkan Guidelines yang diarahkan oleh Kemenparenkraf terkait proses tahapan evaluasi pembukaan bertahap destinasi wisata di Indonesia, pariwisata aman pasca pandemic covid-19 menyangkut hal-hal sebagai berikut:

- Penerapan protocol kesehatan berbasis CHSE (Cleanliness, Health, Safety, dan Environment Sustainability) yang ketat dari hulu ke hilir.

- Penentuan titik krisis berpotensi pelanggaran protocol kesehatan, contoh ventilasi pada ruang indoor yang lebih beresiko sehingga perlu kehati-hatian di setiap titik.

- Aktivitas wisata (terkait durasi, aktivitas yang ditawarkan, jarak antar pengunjung, dsb)

- Penerapan Aplikasi Peduli Lindungi

Dalam kegiatan PKM ini, Pembuatan Peta Digital Wisata Aman Pandemi merupakan salah satu alternative media informasi dan sosialisasi terkait destinasi wisata yang aman setelah pandemic di Desa Cimenyan. Selain itu, peta digital ini juga merupakan langkah awal untuk menilai kesiapan tempat wisata untuk menerima kembali kunjungan wisatawan dengan protocol kesehatan yang dianjurkan. Identifikasi dan anaisis diperlukan sebelum pembuatan peta digital ini untuk mengetahui apakah destinasi wisata di Desa Cimenyan memenuhi persyaratan ruang yang memadai untuk menerapkan protocol kesehatan di masa pendemi.

\section{Potensi wisata aman pandemi di Desa Cimenyan}

Desa Cimenyan memiliki berbagai potensi wisata alam terbuka dengan suguhan pemandangan Bandung dari atas bukit. Deretan kafe dan warung kopi sepanjang jalan desa juga ramai dikunjungi wisatawan dari dalam maupun luar Kota Bandung. Puncak Bukit Bintang, Bukit Moko, Kampoeng Bamboe, merupakan destinasi wisata utama di Desa Cimenyan. Selain itu kafe-kafe dan warung kopi semi outdoor dengan Bandung City view baik pada siang dan malam hari menambah deretan potensi wisata di Desa Cimenyan. Ruang-ruang terbuka, akses udara alami, luas area yang memungkinkan aktivitas yang menjaga jarak, serta penerapan protocol kesehatan yang baik menjadi factor unggulan tempat-tempat wisata di Desa Cimenyan yang diharapkan dapat menjadi alternative wisata yang aman bagi pengunjung di masa pemulihan post pandemic Covid-19.

\section{METODE PELAKSANAAN PKM}

Pelaksanaan program pembuatan Peta Digital Aman Pandemi (pandemic-safe tourism digital mapping) dimulai pada bulan Agustus 2021 sampai dengan September 2021 yang pelaksanaanya didukung oleh pemerintah Desa Cimenyan, Karang Taruna Sinar Harapan Desa Cimenyan, serta warga Desa Cimenyan. Adapun tahapan pelaksanaan diawali dengan diskusi dengan pemerintah Desa Cimenyan, observasi kondisi wilayah khususnya terkait objek-objek wisata serta UMKM di Desa Cimenyan, identifikasi hasil survey, perancangan peta digital, pengumpulan informasi sekunder, pembuatan program peta digital, serta penginputan peta digital pada web desa. 


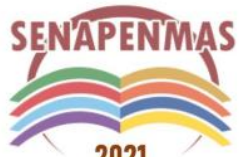

2021
Seminar Nasional Hasil Penelitian dan Pengabdian Kepada Masyarakat 2021

Pengembangan Ekonomi Bangsa Melalui Inovasi Digital Hasil Penelitian dan Pengabdian Kepada Masyarakat Jakarta, 21 Oktober 2021

\begin{tabular}{|ll|}
\hline 2 & Diskusi Awal \\
\hline & Survey dan Observasi Potensi Wisata dan UMKM \\
\hline & Identifikasi dan Analisis Hasil Survey \\
\hline & Perancangan Peta Digital \\
\hline & Programming Peta Digital \\
\hline & Asistensi dan Evaluasi \\
\hline & Sosput peta dalam website desa \\
\hline
\end{tabular}

Gambar 3 . Tahapan pelaksanaan PKM

\section{Diskusi dengan pemerintah Desa Cimenyan}

Pelaksanaan kegiatan ini diawali dengan diskusi dengan Pemerintah Desa Cimenyan. Adapun pihak yang ditunjuk untuk mendampingi kegiatan PKM ini adalah Sekretaris Desa dan Ketua Karang Taruna. Dari hasil diskusi didapat masukan-masukan dan harapan Pemerintah Desa dan Karang Taruna khususnya serta warga masyarakat desa umumnya terkait sektor pariwisata setelah pandemic, dan hal-hal terkait promosi UMKM unggulan di Desa Cimenyan.
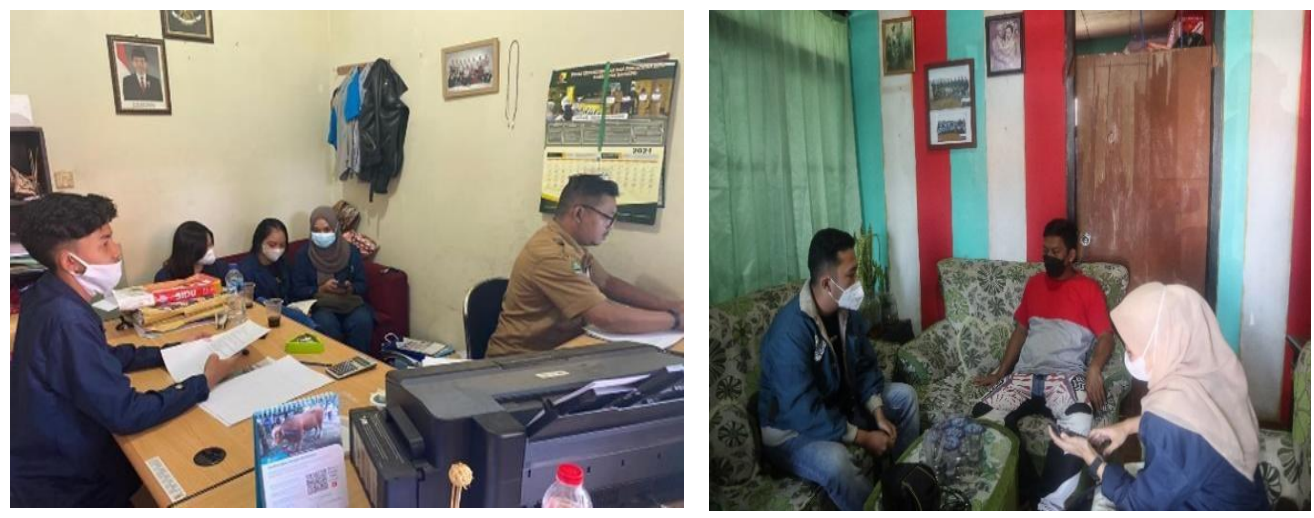

Gambar 4. Diskusi awal dengan pemerintah desa Cimenyan

\section{Observasi kondisi wilayah}

Observasi wilayah ini ditujukan untuk mengetahui keadaan geografis wilayah, potensi dan sumberdaya alam dari Desa Cimenyan selain itu mahasiswa juga menganalisis potensi sumber daya yang ada di Desa Cimenyan untuk dikembangkan dan diberdayakan agar dapat memberikan dampak positif bagi masyarakat maupun pemerintah desa setempat. Dalam observasi ini hal-hal yang diamati meliputi objek wisata, kafe, restoran, warung kopi, serta UMKM unggulan di Desa Cimenyan. Selain observasi dilakukan juga wawancara dengan pengelola, pemilik, serta pihak-pihak terkait untuk mendapatkan informasi sekunder mengenai tempat-tempat tersebut. 


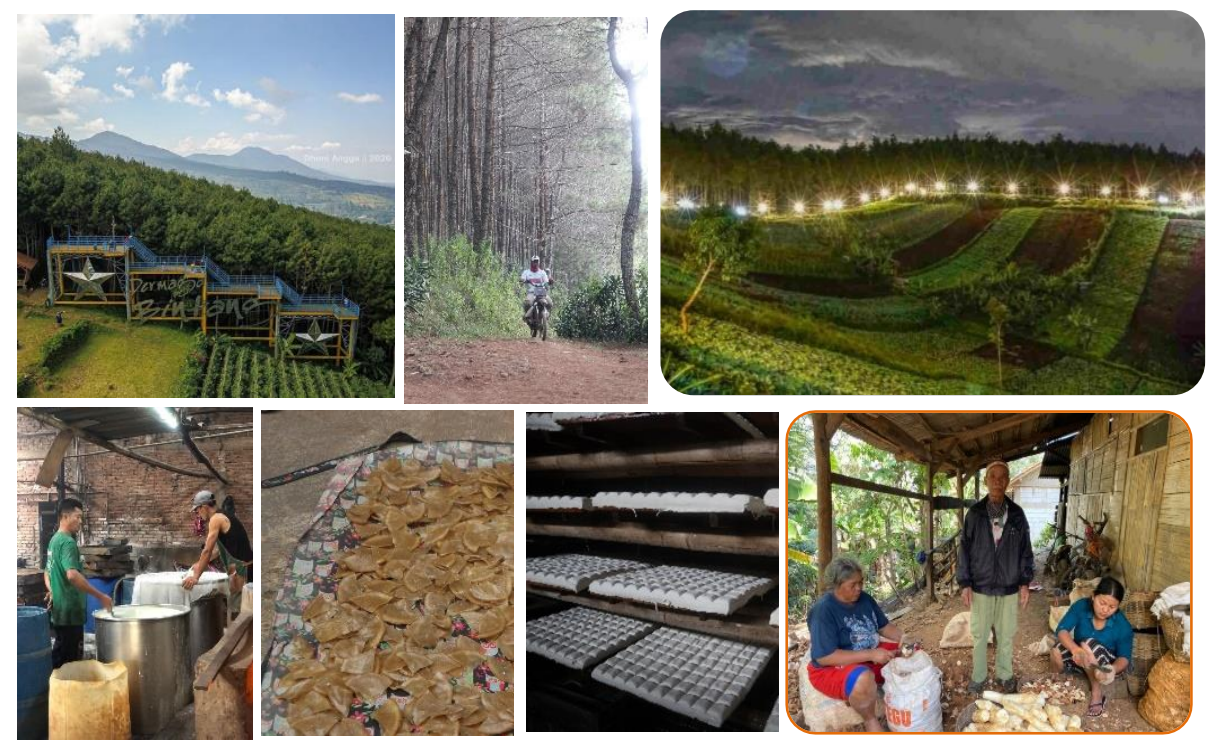

Gambar 4. Observasi tempat wisata dan UMKM potensial di Desa Cimenyan

Dalam kegiatan PKM ini, abdimas memfokuskan kegiatan pada persiapan Desa Cimenyan menghadapi “The Real New Normal", khususnya pada sector pariwisata, perdagangan, dan UMKM. Adapun solusi permasalahan selanjutnya direspon berdasarkan potensi serta permasalahan pariwisata, perdagangan, UMKM, serta kaitannya dengan kebutuhan sector tersebut di masa pasca pandemic covid-19.

Solusi permasalahan terkait pariwisata adalah dengan melakukan digital mapping tempat-tempat wisata outdoor maupun semi outdoor di Desa Cimenyan. Konteks ruangan outdoor maupun semi outdoor sejalan dengan konsep Pandemic-safe tourism dimana ruang-ruang yang terbuka dengan sirkulasi udara luar, berdasarkan studi merupakan ruang-ruang yang lebih minimal dalam menyebarkan virus lewat udara. Digital Mapping ini nantinya akan menghasilkan peta digital yang terintegrasi dengan website Desa Cimenyan sehingga lebih accessible. Informasi tempat wisata berupa foto-foto, Instagram, website, kontak person, hingga link youtube terkait tempat wisata tersebut.

Solusi permasalahan terkait perdagangan, difokuskan pada sektor komersial berupa kafe-kafe dan warung kopi outdoor dan semi outdoor yang menyuguhkan pemandangan Kota Bandung dari atas. Berkaitan dengan pandemic covid 19, sektor komersial yang dipilih adalah kafe, warung kopi, serta restoran yang sesuai dengan prinsip-prinsip rancangan ruang terbuka, memiliki akses langsung dengan udara bebas, prinsip menjaga jarak antar meja dan kursi, serta penerapan protocol kesehatan pada pintu masuk, maupun pegawai. Digital mapping sektor komersial ini diharapkan turut menjadi sosialisasi adaptasi kebiasaan baru setelah pandemic covid 19.

Solusi permasalahan terkait UMKM, adalah dengan menyertakan UMKM unggulan Desa Cimenyan dalam Digital Mapping. Beberapa umkm unggulan Desa Cimenyan yaitu peuyeum, kopi, keripik, kerupuk, dan sayur mayur hasil perkebunan. Melalui digital mapping UMKM di Desa Cimenyan, diharapkan ini dapat menjadi media sosialisasi dan promosi produk UMKM serta dapat menjadi alternative oleh-oleh untuk mendukung pariwisata di Desa Cimenyan. 


\section{HASIL DAN PEMBAHASAN}

Setelah mendapatkan data-data yang dibutuhkan untuk pembuatan peta digital, selanjutnya dilakukan identifikasi dan analisis untuk menentukan objek-objek wisata apa saja yang memenuhi kriteria terkait potensi wisata yang aman pasca pandemic covid 19 .

\section{Identifikasi dan Analisis Hasil Survey dan Observasi}

Identifikasi hasil survey dilakukan untuk memilah-milah objek wisata serta wisata kuliner dan warung kopi yang masuk dalam kriteria wisata aman pandemic (pandemic-safe tourism) melalui pengamatan rancangan lansekap tempat wisata, ruang-ruang terbuka, hingga aspek pemenuhan protocol kesehatan selama pandemic covid 19. Pada kafe dan warung kopi, digital mapping difokuskan pada kafe dan warung kopi dengan konsep ruang outdoor dan semi outdoor serta layout tempat duduk yang memungkinkan untuk diterapkannya social-distancing antar meja. Ruang-ruang dengan akses udara terbuka menjadi salah satu kriteria untuk wisata aman pandemic pada digital mapping ini.

Selain tempat wisata, UMKM juga menjadi objek observasi mengingat UMKM memiliki peranan penting untuk mendukung sektor pariwisata. Berdasarkan hasil wawancara dengan pemerintah desa, salah satu produk unggulan UMKM di Desa Cimenyan adalah peuyeum. Peuyeum cimenyan juga sudah berhasil menembus pasar oleh-oleh Kota Bandung, terlihat dari beberapa UMKM peuyeum yang memasok bahan baku ke beberapa took oleh-oleh besar di Kota Bandung. Selain peuyeum, terdapat beberapa produk UMKM lain di Desa Cimenyan yang berpotensi untuk dikembangkan, yaitu kopi, kerupuk, keripik, tahu, dan lain-lain. Selanjutnya UMKM ini akan dimasukan dalam poin-poin pada peta digital.

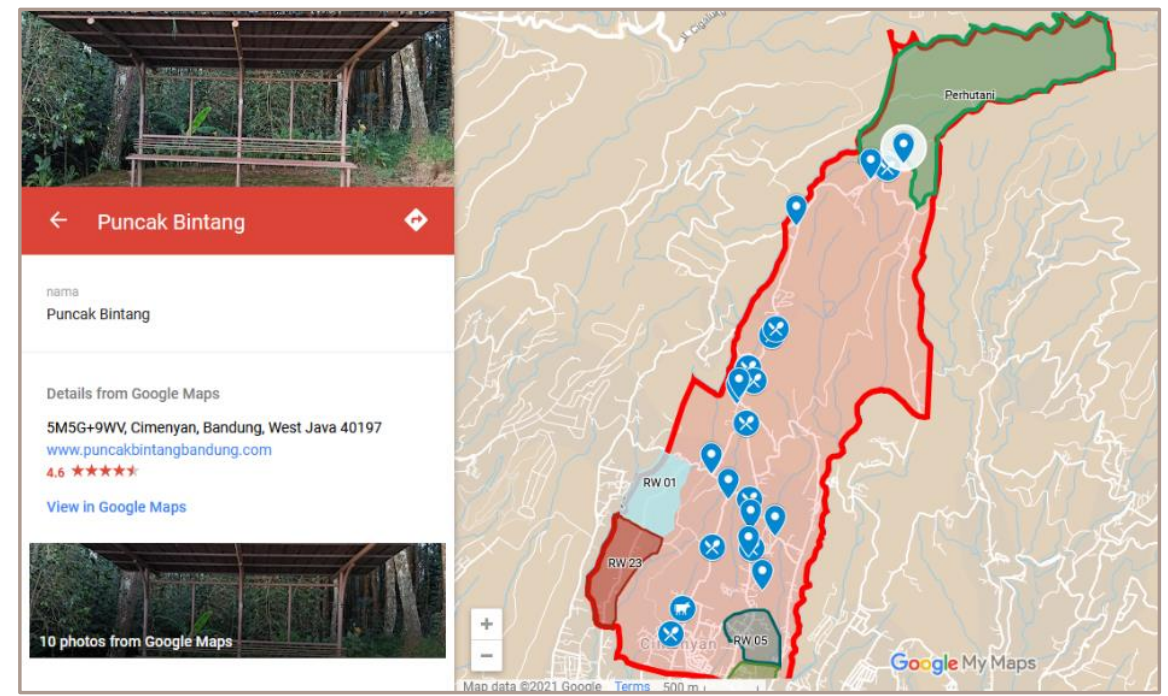

Gambar 5. Mapping potensi wisata aman pandemic dan

UMKM unggulan di Desa Cimenyan

\section{GAMBAR DAN TABEL}

\section{Perancangan ilustrasi peta digital wisata aman pandemi Desa Cimenyan}

Hasil identifikasi dan analisis selanjutnya dijadikan dasar untuk memetakan tempat wisata dan UMKM Desa Cimenyan. Proses perancangan peta digital dimulai dengan tracing peta melalui google maps dan google earth yang disesuaikan dengan batas-batas wilayah Desa Cimenyan. Setelah proses cropping dan tracing selesai, dilanjutkan penambahan-penambahan icon-icon penunjuk "lokasi" dengan menggunakan Software Corel Draw. Icon-icon tersebut sebagian di dapat pada web freepik sehingga memudahkan proses pembuatan ilustrasi peta digital, 
sedangkan sebagian icon-icon lain dibuat secara manual menggunakan software Adobe Ilustrator dan Corel Draw. Tahapan akhir dari perancangan ilustrasi peta digital adalah dengan menambahkan beberapa gambar penunjang untuk membuat ilustrasi menjadi lebih menarik.
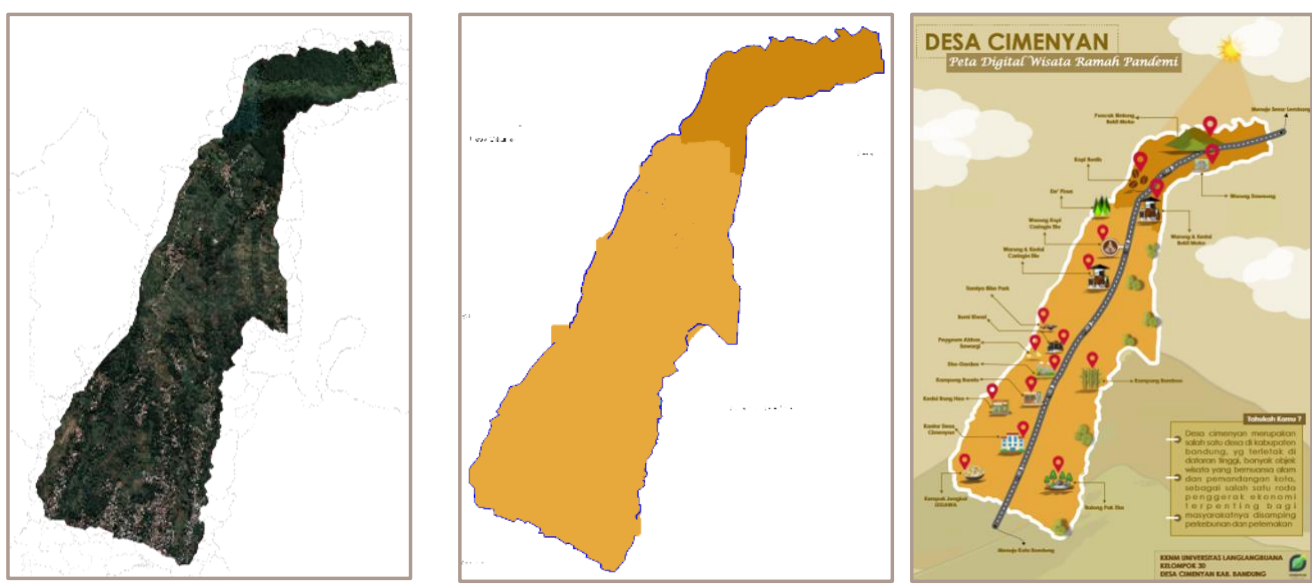

Gambar 6. Tahapan perancangan ilustrasi peta digital

\section{Pemrograman peta digital wisata aman pandemi Desa Cimenyan}

Tahapan selanjutnya setelah desain peta digital dibuat, adalah melakukan pemrograman agar icon-icon pada peta dapat diklik dengan menggunakan software XAMPP dengan Visual Code Studio. Adapun XAMPP berperan sebagai server agar bisa dijalankan di web secara offline. Visual code studio digunakan untuk membuat pemrograman peta digital. Selanjutnya, pemrograman yang telah dibuat menggunakan Visual Code Studio disatukan ke XAMPP untuk melihat apakah program berjalan dengan baik atau tidak. Setelah program diujicoba dan berhasil, selanjutnya dilakukan proses hosting melalui idcloudhost. Hosting berguna untuk membuat server secara online agar dapat diakses oleh semua orang. Adapun domain peta digital Desa Cimenyan yang dibuat oleh tim abdimas adalah http://petawisatacimenyan.my.id/. Setelah selesai proses pembuatan hosting, tahapan selanjutnya adalah memasukkan atau mengunggah file yang sudah dibuat di XAMPP ke hosting. Tahapan akhir dari proses pemrograman peta digital adalah dengan melakukan input peta tersebut ke laman web desa, dengan cara login atau masuk ke server desa desa cimenyan, dan membuat menu halaman baru yaitu 'peta wisata' untuk selanjutnya mengaitkan menu tersebut ke link domain yang telah dibuat.
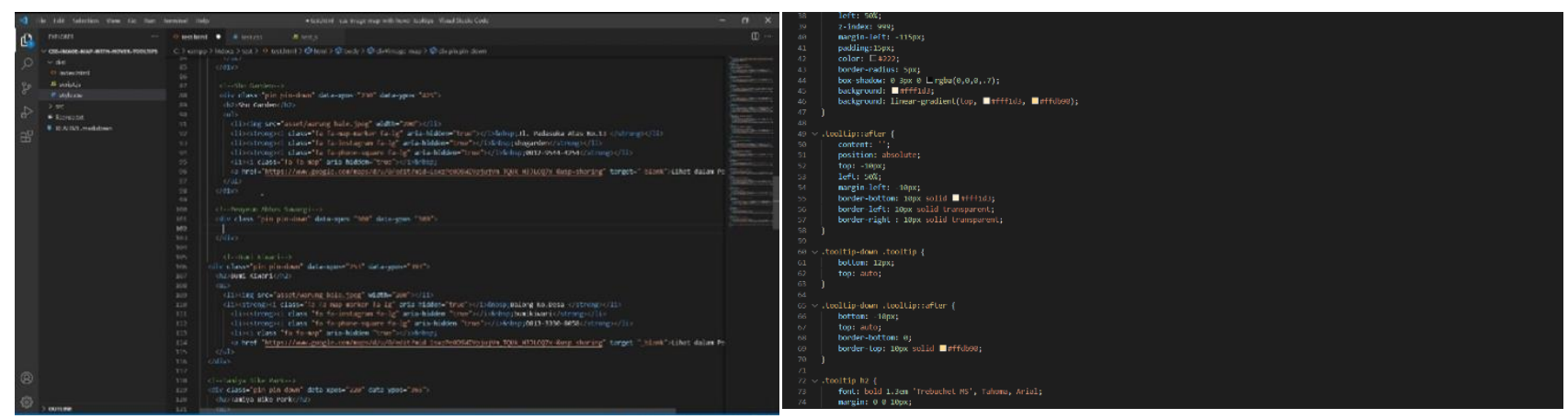

Gambar 7. Pemrograman peta digital menggunakan XAMMP dan visual code studio 


\section{Asistensi dan evaluasi dengan pemerintah desa}

Setelah dummy peta digital rampung, proses selanjutnya adalah melakukan asistensi untuk evaluasi peta wisata digital dengan Pemerintah Desa. Hasil dari asistensi tersebut adalah didapatnya masukan mengenai posisi-posisi icon yang perlu penyesuaian dengan posisi aslinya. Selain itu didapat masukan juga untuk menginput fasilitas public seperti Kantor Polres dan puskesmas dalam peta digital.

\section{Penginputan peta digital 1.0 wisata aman pandemi Desa Cimenyan}

Tahapan akhir dari perancangan dan pemrograman peta digital adalah dengan menginput peta tersebut ke dalam web desa. Untuk memudahkan akses, icon peta wisata dimasukkan dalam menu tersendiri yang selanjutnya saat diklik akan terhubung dengan domain http://petawisatacimenyan.my.id/. Dalam peta ini seluruh icon tempat wisata, kafe, dan warung kopi terpilih dapat diklik dan dapat terkoneksi dengan website-website official maupun youtube review untuk memudahkan pengguna mendapatkan informasi lanjutan mengenai tempat atau UMKM tersebut.

\section{Sosialisasi peta digital melalui artikel di website desa}

Dalam rangka publikasi dan sosialisasi Peta Digital 1.0 Wisata Aman Pandemi di Desa Cimenyan, tim abdimas menggagas penerbitan artikel mengenai peta digital tersebut pada website desa. Peta digital ini juga diharapkan turut mendukung misi Desa Cimenyan untuk menjadi desa digital. Peta ini juga diharapkan akan dapat dikembangkan sesuai dengan perkembangan pariwisata dan UMKM Desa Cimenyan, sehingga di waktu yang akan datang akan datang Peta Digital 2.0, 3.0, dan seterusnya.

Adapun hasil akhir dari Kegiatan Pengabdian Masyarakat di Desa Cimenyan ini adalah Peta Wisata Digital 1.0 Aman Pandemi di Desa Cimenyan yang telah masuk dalam menu pada laman Web Desa. Saat ini peta tersebut sudah dapat diakses dengan hosting tambahan pada domain http://petawisatacimenyan.my.id/. Sosialisasi dan Publikasi Artikel terkait peta ini juga telah terbit pada laman web Desa Cimenyan dengan judul ' Peta Digital Wisata Aman Pandemi Desa Cimenyan'. Diharapkan melalui peta digital ini, promosi wisata aman pandemic mampu meningkatkan kembali jumlah wisatawan yang berkunjung ke Desa Cimenyan sekaligus sebagai media sosialisasi bagi pengelola tempat wisata dan sektor komersial untuk tetap mematuhi protocol kesehatan pasca pandemic covid 19. Peta digital ini juga diharapkan mampu berkontribusi dalam sosialisasi UMKM unggulan Desa Cimenyan yaitu peuyeum, keripik, dan kopi. Selain itu, komoditi unggulan UMKM ini juga diharapkan dapat mendukung sektor pariwisata dalam penyediaan oleh-oleh khas local Desa Cimenyan.

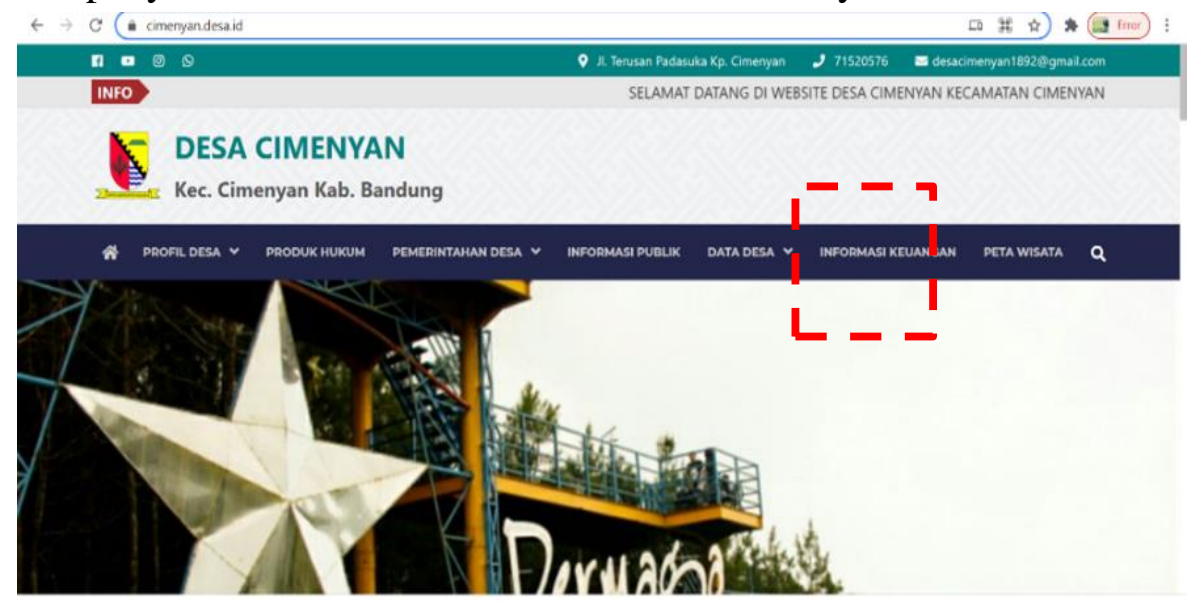


Gambar 8. Peta wisata dalam website Desa Cimenyan
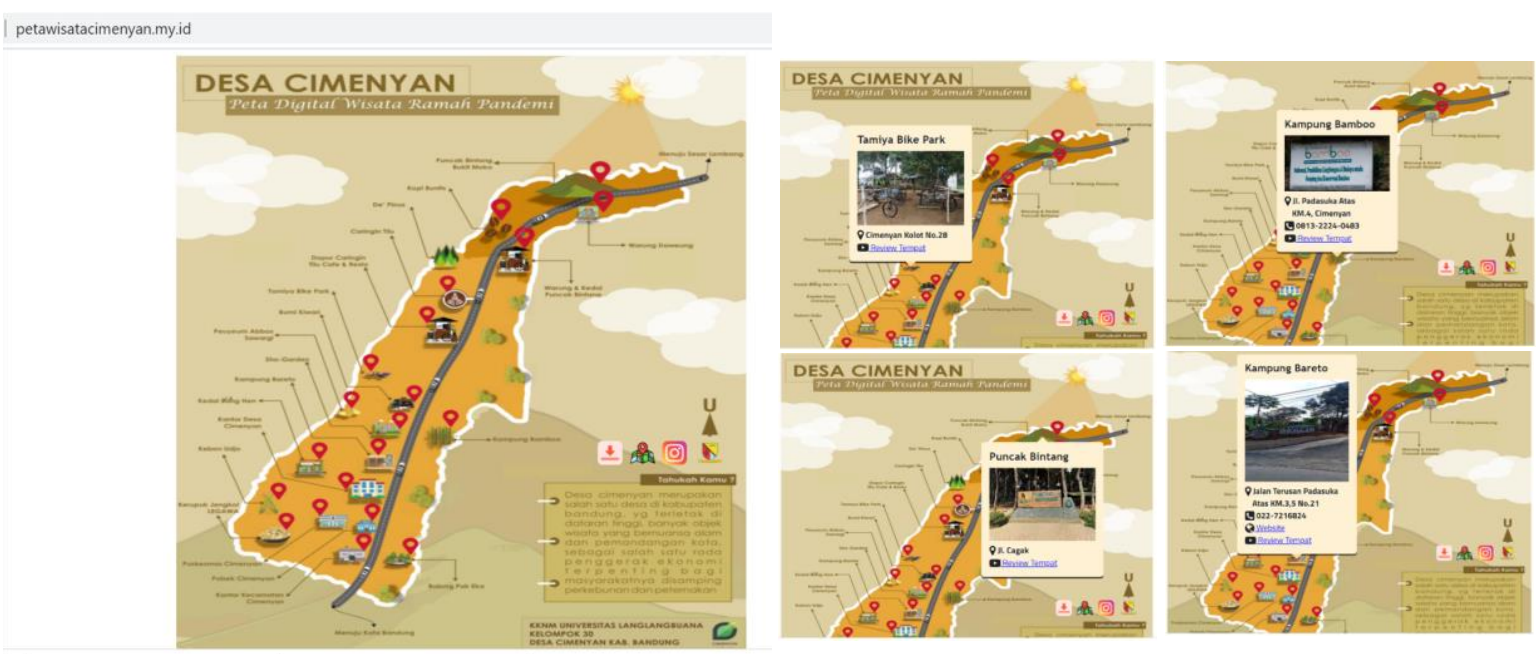

Gambar 9. Peta digital wisata aman pasca pandemi di Desa Cimenyan

Kegiatan PKM di Desa Cimenyan ini melibatkan lintas bidang keilmuan dari anggota tim abdimas, yaitu bidang Arsitektur, Ekonomi, serta Teknik Informatika. Bidang keilmuan arsitektur diperlukan untuk identifikasi tempat wisata aman pandemic di Desa Cimenyan. Bidang keilmuan ekonomi diperlukan untuk melakukan identifikasi sektor terdampak pandemic serta identifikasi UMKM di Desa Cimenyan. Bidang keahlian informatika dibutuhkan untuk pemrograman peta digital agar dapat diinput dalam web desa serta dapat diakses oleh masyarakat yang lebih luas.

Dalam perancangan peta digital, digunakan software Corel Draw dan Adobe Illustrator. Sebagai pendukung digunakan aplikasi canva dan freepic untuk membuat ilustrasi menjadi lebih menarik. Pada tahap pemrograman peta digital, digunakan software XAMPP dan Visual Code Studio. Hosting pada domain http://petawisatacimenyan.my.id/ ini didapat melalui idcloudhost.

Peta Wisata Digital Aman Pandemi Desa Cimenyan 1.0 ini diharapkan dapat menjadi titik awal maupun pilot project bagi inisiasi peta-peta digital lainnya untuk desa-desa di Kecamatan Cimenyan yang memiliki potensi wisata dan UMKM unggulan. Keterlibatan Karang Taruna dengan SDM yang relative mudah mempelajari teknologi menjadi salah satu factor penentu keberlanjutan permutakhiran peta digital ini sehingga transfer knowledge antara tim abdimas dengan pihak Karang Taruna Desa Cimenyan menjadi evaluasi bersama setelah kegiatan PKM dilaksanakan.

\section{KESIMPULAN DAN SARAN}

Peta Digital Wisata Aman Pandemi di Desa Cimenyan merupakan langkah persiapan desa menuju kondisi "the real new normal" ketika sebuah desa wisata bersiap kembali untuk menerima kunjungan wisatawan. Peta digital menjadi salah satu media informasi, sosialisasi, sekaligus edukasi bagi tempat wisata sekaligus pengunjung untuk tetap mengedepankan aspek kesehatan dan keselamatan dalam rangga mencegah pandemic covid-19 menyebar lebih luas ketika roda ekonomi pariwisata berjalan kembali. Rencana tindak lanjut dari Peta Digital 1.0 ini adalah dengan dikembangkannya Peta Wisata Digital 2.0 yang lebih informatif yang lebih interaktif. 


\section{Ucapan Terima Kasih (Acknowledgement)}

Ucapan Terima Kasih penulis sampaikan kepada LPM Universitas Langlangbuana serta panitia KKNM yang telah memfasilitasi kegiatan PKM ini. Penulis juga berterimakasih kepada Pemerintah Desa serta warga Desa Cimenyan yang telah sangat suportif dan kooperatif selama kegiatan PKM ini berlangsung.

\section{REFERENSI}

Aryani, Vitria dkk. (2019). Buku Pedoman Desa Wisata. Jakarta : Kementrian Pariwisata.

Mangeswuri, Dewi Restu (2021). The Prospect Of Increasing Domestic Tourism During The Covid-19 Pandemic. Jakarta: Info Singkat - Puslit DPR.

Revindo, Muhammad dkk ( 2020). Dampak Pandemi Covid-19 terhadap Pariwisata Indonesia: Tantangan, Outlook dan Respon Kebijakan. Jakarta : Pusat Kajian Iklim Usaha dan GVC LPEM FEB UI.

Rubiyanti, Yayu. (2021). Konsep Ecotourism Masa Transisi Pandemi Covid-19 di Desa Wisata Kerajinan Bambu Brajan Yogyakarta. LINTAS RUANG: Jurnal Pengetahuan dan Perancangan Desain Interior. 8. 39-47. 10.24821/lintas.v8i2.5202.

Spencer, A. and Tarlow, P. (2021), "Pandemics and Tourism Safety", Tourism Safety and

Security for the Caribbean (Tourism Security-Safety and Post Conflict Destinations), Emerald Publishing Limited, Bingley, pp. 85-94.

https://www.beritasatu.com/nasional/625495/destinasi-wisata-yang-sehat-dan-aman-akan-jadiprimadona-pascapandemi-covid19

https://kemenparekraf.go.id/ragam-pariwisata/Tren-Pariwisata-Indonesia-di-Tengah-Pandemi https://promkes.kemkes.go.id/liburan-aman-di-masa-pandemi https://cimenyan.desa.id/ https://www.cimenyan.desa.id/artikel/2021/9/9/peta-digital-ramah-pandemi-desa-cimenyan. https://pedulicovid19.kemenparekraf.go.id/tahapan-evaluasi-uji-coba-pembukaan-destinasiwisata-di-tanah-air/ https://www.uph.edu/wp-content/uploads/2020/06/290520_MPAR Webinar_UPH_The-Futureof-Tourism-and-Hospitality-Business-Model-in-the-New-Normal_Frans-Teguh.pdf 
Seminar Nasional Hasil Penelitian dan Pengabdian Kepada Masyarakat 2021

Pengembangan Ekonomi Bangsa Melalui Inovasi Digital Hasil Penelitian dan

Pengabdian Kepada Masyarakat

Jakarta, 21 Oktober 2021

(halaman kosong) 